\title{
ТЛУМАЧЕННЯ ЛЮДСЬКОГО БУТТЯ В ФЕНОМЕНОЛОГІЇ ТА ЕКЗИСТЕНЦІАЛІЗМІ В КОНТЕКСТІ СУЧАСНОÏ ФІЛОСОФІї ІСТОРІї
}

\section{Т.В. Кушерець}

В українській філософії історії продовжуе панувати натуралістичний підхід до розуміння чинників історії $\mathrm{i}$, як наслідок, фаталістичне тлумачення української історії, про шо, свого часу, слушно зауважував В. Липинський. В роки незалежності вона звертаеться не до сучасної історіографії та філософії історії з їх гуманістичним тлумаченням чинників історії, піднесенням людини як суб‘екта історії, а повертаеться до позитивістської історіографії, яка на Заході піддавалась серйозній критиці вже на початку XX століття. Це означає, що українська філософія історії наразі не змогла піднятися до філософської рефлексії над історичним процесом, у тому числі, над його природними чинниками, що стало умовою подолання натуралізму в західній історії. «Тим самим маргінальність історичної думки проявляється не лише у постійній залежності від західної філософсько-історичної думки, але й в однобічності сприйняття ऑї надбань. Вона й нині «доношує» ті філософські уявлення, той її зміст і ті настанови, які були відкинуті уже на межі XIX-XX ст. Український історичний дискурс недооцінюе в нале-

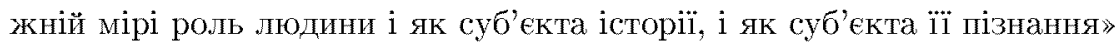
$[9$, c. 27$]$.

Слушним виглядае зауваження Н. Яковенко про існування асиметрії між українською та західною історіографією, що проявляється, окрім іншого, у несумірності методів, підходів, понятійно-категоріального апарату. Така асиметрія $е$ специфічним проявом опозиції «маргінальне (периферійне) - центральне (магістральне)» в історичній нау-

Актуальні проблеми духовності:

3б. наук. праць / Ред.: Я.В. Шрамко

Вип. 11. - Кривий Ріг, 2010, 58-69

ISSN 2076-7382 
ці. Іїі подолання передбачає «вирівнювання асиметрії у дискурсах української та західної історіографії» [16, с. 14]. Таке вирівнювання, а отже й подолання маргінальності української історії, Н. Яковенко вбачає в оновленні категоріально-методологічного апарату української історичної науки. Погоджуючись 3 даним положенням, зазначимо, що таке оновлення для уникнення його еклектичності і механічного характеру передбачає, перш за все оновлення, а вірніше створення, загального філософського образу української історії.

Якщо звернутися до питання про новий образ історії, який так важко формуеться у свідомості пострадянської людини, то слід, як вважає сучасний український філософ В. Табачковський, мати на увазі наступне. Традиційний підхід до тлумачення історії був пов'язаний 3 так званим картезіанським репрезентаціанізмом, націленим на пошук свого роду абсолютних сутностей буття загалом та людського буття зокрема. У руслі такого пошуку складалися уявлення, котрі можна назвати есенційними (лат. «есенція»-сутність). Ці уявлення мали на меті передусім осягнення єдиної першосутності будь-якого явища.

Один із відомих критиків есенціалізму К. Поппер так описує його генеалогію. Платон успадкував есенціалізм від Геракліта. Фундаментальне обгрунтування цій тенденції дав пізній Арістотель, надалі жнімецька класична філософія, особливо Гегель, марксизм та ряд інших філософських течій. Тим, на думку Поппера, склалася своєрідна «оракульська філософія», що стала теоретичною передумовою тоталітаризму. Вона розглядає історію як лінійно-поступальний рух до якогось абсолютного стану. Схематизм подібних поглядів на історичний процес Поппер назвав «злиденністю історицизму». «Але на противагу традиційному класичному, есенційному баченню історичності виникає бачення екзистенційне. Йому також не чужий пошук того, що об'єднує людей, проте з позицій плюралізму» $[10$, с. 8$]$.

Завданням данної статті $є$ розкриття значення загальнофілософського тлумачення людського буття в феноменології та екзистеціалізмі для розвитку сучасної філософії історії та пояснення на їх основі зростання ролі та розмаїття виявів особистісного фактору в історії, невід'ємну від нього відповідальність суб'єкта історичного діяння.

Як вдало зауважив В. Табачковський, «для того аби осягнути саму історію, необхідно дати собі звіт у тім, що е людина». 3 іншого боку, кожен, хто замислюється над феноменом людини, доходить висновку, що «людське існування саморозгортається у часі, його всезагальність та індивідуальні вияви розкриваються через перебіг модусів часу, історичність» $[10$, с.5]. Саме екзистенціалізму, який спирається на здобу- 
тки феноменологічної філософії, вдалося справитися з цим двоєдиним завданням, а саме: 1) осмислити феномен історії під кутом зору такої сутнісної властивості людського способу буття як свобода; 2) через перегляд фундаментальних уявлень про час розробити концепцію історичністі як конституюючої умови людського буття.

Фундаментальна праця М.Хайдеггера «Буття і час» (1927) присвячена перетворенню поняття час у ключове поняття посткласичної філософії. Мислитель продовжуе і поглиблюе ту тенденцію, яка була започаткована в феноменології Гуссерля. Розгляд буття в горизонті часу має початок у гуссерлівських лекціях 3 феноменології внутрішньої свідомості часу, які він готував до друку як раз у 1927-1928 pp. Слідом за своїм учителем Хайдеггер саме в часі вбачав фундамент онтології. «У правильно зрозумілому та правильно експліцийованому феномені часу, - писав він, - закорінена центральна проблема усієї онтологї» $[11$, с. 18]. Один із найважливіших результатів роботи Гуссерля та Хайдеггера полягає у тому, що глибоко вкорінене у традиції, яка розпочалася ще з Парменіда, протиріччя між буттям і часом, суттевим і тимчасовим, між вічним (ейдетичним) та минущим (історичним) несподіваним чином перетворюється у свою протилежність. «Тепер сам час, належним чином осмислений, стає граничною онтологічною основою, що приводить у рух усю систему фундаментальних філософських понять» $[15$, с. 15$]$.

На думку Хайдеггера, найглибше дослідження часу було здійснене Арістотелем, оскільки саме ним були розглянуті усі важливі проблеми, що стосуються часу, які пізніше так чи інакше обговорювались у подальшому розвиткові філософії. «Можна сказати, що у наступні часи так і не вдалося суттєво вийти за межі Арістотелевої розробки проблеми часу, за виключенням, можливо, деяких місць у Августина та Канта, але й вони, тим не менш, в основному дотримувалися Арістотелевого розуміння часу» $[13$, с.310-311]. Визначення часу, яке дав грецький мислитель, Хайдеггер вважав геніальним. Згідно з Арістотелем, час $\boldsymbol{\varepsilon}$ не що інше, як число руху по відношенню до попереднього та подальшого. Найбільш проста форма руху - це переміщення, хоча цей перехід від попереднього до подальшого, від «до» до «після» здійснюеться і при якісних змінах як перехід «від чогось до чогось». Арістотель продовжив традицію грецької філософії розглядати час крізь призму вічності. Він розмежував позачасові істоти, які $є$ незмінними, від істот тимчасових і змінних. До перших відніс вічний двигун, духів небесних сфер, а також завжди тотожний собі розум.

Саме прагненням осягнути час не тільки у його відмінності від ві- 
чності, але й у зв'язку з нею, пояснюеться підкреслюваний грецькими філософами пріоритет одного із модусів часу - теперішнього-перед минулим та майбутнім. Для Арістотеля, зокрема, теперішне, момент «тут» є ніби початком самототожності у самому часі, цієї нетривкої, безперервно змінюваної стихії. «Хайдеггер постійно повторюе альтернативну тезу про те, що „тепер“ протяжне і розпростерте, тобто являє собою континуум, безперервність, що ,тепер“ - це сам час, а не неподільний початок (межа) часу, як стверджував Арістотель, тому що хоче ліквідувати зв'язок часу з вічністю, зв'язок, який Арістотель має на увазі, коли визначає „тепер" як неподільний початок часу» $[1$, c. 167 168]. Цей зв'язок часу з вічністю зберігався впродовж більш ніж двохтисячолітнього існуванння метафізики та послужив підгрунтям для побудови основних класичних систем філософії історії, тому ми дозволили собі коротко охарактеризувати його суть.

На думку Хайдеггера, Гуссерль переглядає основні принципи метафізики, у тому числі і по відношенню до часу, але робить він це не досить радикально. У його працях ще не до кінця знищені корені метафізики, хоча багато зроблено для їх подолання. Абсолютна тривалість у феноменології Гуссерля встає на місце абсолютного Я німецького ідеалізму, зокрема у Фіхте, і Хайдеггер справедливо побачив у цій абсолютній тривалості феноменологічний аналог позачасовості. Він також не міг не помітити прагнення Гуссерля утвердити переважаюче значення моменту «тепер», що відіграє у структурі трансцендентальної суб'єктивності роль, яка нагадує роль «тепер» у Арістотеля, виступаючи позачасовим «початком» часу. Сам Хайдегтер остаточно позбавляється залишків «метафізичного коріння», стверджуючи конечний характер справжнього часу. «Часовість по суті екстатична. Часовість укорінена в майбутньому. Початковий час е скінченним» $[11$, с. 331]. На відміну від традиційної метафізики, яка покладала «телос» часу в моменті «тепер», Хайдеггер стверджуе, що основа часу - майбутне. А оскільки найдостовірніше майбутне для людини - це смерть, то саме вона являе собою онтологічний горизонт часу.

Які ж методологічні наслідки для філософії історії мала радикальна зміна уявлень про час, розпочата Гуссерлем та завершена Хайдеггером? На думку В. Табачковського, «парадигма безкінечності часу, принаймні, не сприяе відповідальному ставленню масового індивіда ні до природи, ні до культури. Культурно-гносеологічна передумова цього в тім, що безкінечний час е безякісним і відтак-безособовим. Людське ж існування здійснюеться в якісних, ціннісно насичених, індивідуально особистісних просторово-часових параметрах» [10, с. 47]. 
Тому у «Бутті та часі» Хайдеггера людський час тлумачиться через такі екзистенціали як тривога, совість, страх, провина, турбота.

Як зауважив Г. Гадамер, будь-яким безособовим формам несправжнього існування Хайдеггер протиставив справжність самобутнього тут-буття, яке усвідомлює власну кінечність та з усією рішучістю приймае їі. Прадавню загадку смерті поставлено у центр філософування, завдячуючи чому пролунав на всю силу заклик до вибору кожною людиною власного самобутнього існування. Хайдеггер закцентував увагу на тій обставині, що людське тут-буття самоздійснюеться тільки завдячуючи «хвилюванню турботи». Стурбоване ж власним буттям тутбуття - то не що інше, як власне майбуття. Турбота, за Хайдегером, означає у найуніверсальнішій світоглядній перспективі здатність людини «вистояти, стаючи відкритою для відкритості буття» [12, с. 31].

Навіть якщо сутність самої історії повністю затінена для сучасної людини, вона зберігае здатність до історіографічного збирання відомостей та повідомлення й передачі за традицією; зберігається також історичний досвід, і ми приймаємо до уваги історіографічні повідомлення так, ніби це само собою зрозуміле. «Ми володіємо при цьому якимось надто невизначеним й плутаним уявленням про „історичність історії"» $[12$, с. 150]. Свідченням такого уявлення $\epsilon$, на думку філософа, пануюче донині технізовано-«історіографічне» подання історичних подій, коли історія тлумачиться як поле, що на його терені здійснюється подія, котра тут же відходить у минуле. Те ж саме стосується «бездумного полювання за майбутнім», вираховування його образу «шляхом проекції напівосмисленого сьогоднішнього на туманне завтра». Такі уявлення також $\boldsymbol{e}$ техніко-обчислюваними. Але ніяке «історіографічне подання історії» як «послідовності пригод» не наблизить її до сутнісних витоків, прихованих у «події істини буття». Гонитва за майбутнім як за самоціллю не враховуе того, що поки ми не осягнемо думкою того, що є, ми ніколи не зможемо належати тому, що буде.

Саме тому вислів «Майбутнє вже почалось», на думку Хайдеггера, є невірний. Майбутне ніколи не може початися, але завжди зачіпає його відсутність, як присутність «ще-не-наявного», так само як і відсутність минулого, як «вже-не-наявного». Проте наступне як ще-ненаявне несе 3 собою вже-не-наявне, те, що здійснилося, а це останне «тягне» своє власне майбуття. Отже, вже-не-наявне, ще-не-наявне та наявне постійно тяжіють одне до одного. Але якщо минуле і майбутнє бентежать світоглядну свідомість як відсутність, то наявне, сучасне $е$ присутнім. Саме воно є сутнісним виміром історичності буття, і полягає цей вимір у тому, що буття постає «як присутність та впускання 
присутності, тобто відкриття потаемності» [12, с. 398-401].

Подібне «відкриття потаемності» стало ознакою неесхатологічного історизму або ознакою «історизму екзистенції, в якій наявне постае не як мікроскопічний „спалах“ у місці перебігу минувшини в майбуття, а як самостійне смислове осереддя історичного способу буття і роду людського, і кожної окремої індивідуальності. Осереддя, що завдяки йому суб $є$ єк життєдіяльності усвідомлюе унікальну значущість не якихось особливих („вищих“, „сакральних“ тощо) відтинків історичного часу, а кожного $з$ цих відтинків, сплетених воєдино. Бо саме через цю сплетеність унікальних моментів історичного часу кожен 3 нас, прагнучи до в.ласної мети, водночас здатен щоразу повертатися до власних витоків. А відтак - здатен постійно підтримувати „пульс" того, що зароджується, себто пульс становлення, довіряючи цьому становленню та, водночас, залишаючись вірним собі» $[10$, с. 50-51].

Хайдеггер визначае історію як здійснювану в часі специфічну ідею присутності, зокрема так, що «минуле» в бутті-один-з-одним і разом 3 тим те, що передається по традиції, продовжує впливати на події. Смисловий зв'язок елементів цього визначення мислитель вбачає в тому, що вони стосуються людини як «суб'єкта» звершень. 3 її фактичною присутністю як буттям-у-світі є всякий раз і світова історія. «Історичний не позасвітовий суб'єкт, а суще, котре екзистуе як буття-у-світі. Подія історії $\boldsymbol{e}$ подія буття-у-світі. Історичність присутності $є$ по суті історичність світу, який на основі екстатично-горизонтної часовості належить до плинності останньої» [11, с. 388].

Думка, що осмислюе буття, за Хайдеггером, е історичною. Немае ніякої «систематизуючої думки», а поряд $з$ нею для ілюстрацій - різноманітних систем минулих думок, як, наприклад, гегелівська систематизація, що зробила «закон своєї думки законом історії». «Є у більш первиннім осмисленні, історія Буття, котрій належить думка як пам'ять цієї історії, що самою ж історією здійснюеться» [14, с. 332]. Така пам'ять принципово відрізняється від підсумовування подій, бо те, що відбулося не відходить у минуле. Події історії здійснюються як послані істиною Буття із нього самого, Буття стає долею. Оскільки воно $є$ і дарує себе, його не можна знищити або спростувати, його можна лише прийняти. «Завдання людської присутності як первинного суб'єкта історії Хайдеггер вбачае у ек-статичному перебуванні поблизу буття, охороні та турботі про нього. Воно - не здійснення самоствердження ego cogito i не дійсність суб'єктів, що взаемодіють між собою і у такий спосіб приходять до самих себе» [4, с. 140].

Особистісно-подієве тлумачення історії є її суб'єктивним виміром, 
однак таким, що переростає в інтерсуб'єктивний, індивідуальним, котрий переходить у загальнолюдський. Тому було б неправильним зараховувати феноменологію та екзистенціалізм до тих напрямків, які розробляють «різноманітні види концептуалізації ,історичності людини"» [2, с. 13], безвідносно до сощіального аспекту людського існування. Особливо переконливо про це заявив М. Мерло-Понті, який вважав, що екзистувати - означае бути у світі не лише природному, але й соціальному. Він закликае повернутися до соціальності, яка є виміром нашої екзистенції та 3 якою ми вже пов'язані до будь-якої об'єктивації. «Однаково хибним є розуміння себе в суспільстві як об'єкта 3-поміж об'єктів та суспільства як об'єкта мого мислення; обидві помилки пов'язані $з$ визначенням суспільства як об'єкта. $\langle\ldots\rangle$ Сопіальність вже тут, коли ми і1ї пізнаємо, або говоримо про неї» [6, с. 418-419]. Наші стосунки із суспільством та світом набагато глибші за будь-яке сприйняття або судження.

На думку Мерло-Понті, абсолютна суб'єктивність є лише абстрактним поняттям мене самого. Потрібно щоб у формах найрадикальнішої рефлексії людина осягала навколо своеї абсолютної індивідуальності «ніби якусь смугу загальності та щось на кшталт соціальної атмосфери» $[6$, с.511]. Людина не може ігнорувати іншого. Вона сама змушує іншого бути для неї, і сама вона змушуе обох, і себе і іншого, бути людьми. «Необхідно спочатку знайти ще до поділу співіснування Я та іншого в ,інтерсуб'єктивному" світі. I тоді на цьому грунті саме соціальне тільки і здобуде свое значення» [5, с.95]. Усвідомлення соціального світу як безперервного поля або виміру екзистенції має глибокі методологічні наслідки для розуміння історії та людини як історичного суб'єкта.

Подвійність та обтяженість екзистенції французький мислитель виражає через поняття «конкретний суб'ект». «Загальність та індивідуальність суб'єкта, суб'єктивність кваліфікована та суб'єктивність чиста, анонімність „Оп“ та анонімність свідомості не е двома концепціями суб'єкта, з яких філософія могла б обирати; це два боки однієї унікальної структури, якою є конкретний суб'єкт» [6, с. 513]. Навколо наших планів дій та власне індивідуального проекту, яким ми є, Мерло-Понті визнае зону загальної екзистенції, вже реалізованих проектів та значень, які постають між нами та речами і визначають нас як людину, робітника чи буржуа. 3 того моменту, коли ми почали існувати, загальність вже втрутилась, нею опосередковуеться наша присутність у нас самих, ми вже не $\boldsymbol{\varepsilon}$ чистою свідомістю відтоді, як природне та соціальне середовище припинило бути чимось невизначеним та криста- 
лізувалося в якійсь ситуації. «Внутрішне . . - це не якесь „приватне життя", а інтерсуб'єктивність, котра опосередковано пов'язуе нас зі своєю історією. Коли я виявляю, що соціальне - це не тільки об'єкт, а передусім - моя ситуація, і коли я пробуджую у собі свідомість цього мого соціального, вся моя сучасність, що стала для мене теперішнім, а через неї і все минуле, котре я тепер здатен по-справжньому осмислити як сучасне, яким воно колись і було, вся узгоджена і неузгоджена дія історичної людської спільноти, - явно постають у моєму живому теперішньому» $[7$, с. 15$]$.

Співіснування в одній ситуації та відчуття її схожості здійснюється не завдяки порівнянню, коли кожен спочатку ніби живе в-собі, а завдяки їх діям та завданням. Ці ситуапії не передбачають жодної ясної оцінки, і навіть якщо є якась неясна оцінка, то це скоріше «поштовх свободи» проти невідомих обставин. Так, наприклад, підвищення цін або страйк на сусідньому підприемстві призводить до рішення окремого робітника, що «так далі жити не можна, потрібно, щоб щось змінилося». Цю потребу кожен відчуває на прикладі власних труднощів та в глибинах своїх окремих суджень. «Ані фатум, ані вільна дія, яка його руйнує, не $є$ представленими, вони $\varepsilon$ пережитими $з$ усією їхньою подвійністю» $[6$, с. 507].

Класова свідомість народжуеться тоді, коли люди відчувають синхронність свого життя та життя інших людей, спільність своєї долі. На думку Мерло-Понті, якби людина робила сама себе робітником, націоналістом або революціонером за допомогою абсолютної ініціативи, якби нічого не потребувало свободи, то тоді б історія не мала б ніякої структури, в ній не можна було б помітити жодної події і все могло б походити з усього. Тоді б в історії не було б ні імперій як відносно стабільних історичних форм, яким би можна було б давати ті чи інші ймовірні характеристики, ні соціальних рухів періоду революційної ситуації та періоду стабілізації. Історія тоді зовсім не рухалась би, i, розглядаючи навіть дуже короткий період часу, ми не могли 6 стверджувати, що події мали такі-то наслідки. «Проте, якщо історія дійсно нездатна нічого зробити без свідомостей, які їі підхоплюють, i, таким чином, визначають, якщо внаслідок цього, вона не може бути віддаленою від нас як певна зовнішня сила, що нав'язуе нам свої цілі, то саме $з$ тієї причини, що вона завжди є пережитою історією, ми не можемо відмовити їй хоча б у фрагментарному сенсі» [6, с.512].

Мерло-Понті вважае, що те, «що називають сенсом подій, не $є$ ані ідеєю, яка їх продукує, ані випадковим наслідком їхнього з'єднання. Сенс подій - це конкретний проект майбутнього, який виробляеться 
соціальним співіснуванням, виробляеться в „Оп“ до будь-якого особистого рішення. $<\ldots>$ Кожна людина, враховуючи всі можливості індивідуальної свободи, прагне відпочити та скористатися здобутим завдяки тій функціональній та узагальненій екзистенції, яка робить 3 неї суб'єкта історії» [6, с. 512]. Загальність «ролі» та ситуації приходять на допомогу індивідуальному рішенню і в цьому обміні між ситуацією та тим, хто її підтримуе, неможливо відокремити «внесок ситуації від «внеску свободи». Людська історія, на думку Мерло-Понті, мае всю подвійність сенсу - він є, але він визначається в процесі становлення, розгортання історії. «Ми не стверджуемо, що історія від початку та до кінця має один-единий сенс, так само як не має такого сенсу індивідуальне життя. Ми хочемо сказати, що в усіх випадках свобода змінюе його, підхоплюючи той сенс, який історія пропонувала йому певної миті, трансформуючи його у той чи інший спосіб. Завдяки цій пропозищії теперішнього моменту ми можемо відрізнити авантюриста від державної людини, історичну ілюзію від істини епохи. Отже, якщо наші погляди на минуле ніколи не осягають аб́солютної об'єктивності, вони так само не мають права бути свавільними» [6, с. 513].

Смисл історичної ситуації є проблемою співіснування або Mitsein; історія існує тому, що люди є єдиним цілим, а не суб'єктивними та ізольованими молекулами, котрі додавалися б одна до одної. Вони $е$, навпаки, істотами спрямованими на ставлення до іншого, як на становлення інструмента їхньої власної істини. Отже існуе смисл історії, що є тим смислом, котрий люди, проживаючи, дають своїй історії. «Сьогодні, як і сто років тому і як тридшять вісім років тому, залишається істинним, що ніхто не є суб'єктом і ніхто не $є$ вільним на самоті, що вільні люди суперечать один одному і залежать один від одного, що історія є історією їхньої боротьби, і це накреслено і видно в інститутах, цивілізаціях, впродовж великих історнчних звершень, що існують засоби їх зрозуміти, їх розмістити в системі, згідно точної та визначеної iерархії, принаймні як різні епізоди одного життя, про що кожен має досвід і може передати нащадкам» (цит. за: [5, с. 134]).

Мерло-Понті вказуе не тільки на можливість, а навіть на необхідність поєднання подієвого виміру історії зі структурним, на чому так активно наголошуе сьогодні західна філософія історії. Так, П.Берк зауважує, що історикові необхідно «мати справу не лише 3 послідовністю подій і свідомими учасниками подій, але також зі структурами - інституціями, стилями мислення тощо, - незалежно від того, чи ці структури впливають на події як гальмо, чи як каталізатор» $[8$, с.353]. Константні структури і миттєві події є взаємозалежними, але 
не розчиняються один у одному, оскільки структури формують умови для перебігу подій, а події дають можливість розпізнавати і проаналізувати самі структури.

Екзистенційне бачення історії дозволяе розглядати громадянські війни та інші соціальні конфлікти і процеси під різними кутами зору. Голос кожного історика подається не як підсумковий синтез, а як просто один із голосів, нарівні з іншими. Такими голосами можуть бути як голоси 3 боку «переможців», так і голоси 3 боку «переможених». Р. Козеллек зауважує, що історія перших зконцентрована на тій послідовності подій, яка завдяки його власним досягненням увінчалась перемогою. Первинний досвід переможених полягає в тому, що все сталося всупереч їхнім планам і сподіванням. «При спробах осмислення на методичному рівні їм доводиться брати на себе важкий тягар доказування, аби пояснити, чому щось трапилось всупереч задуманому. Ця обставина штовхае до пошуку коротко- чи довготривалих причин» [3, с.87]. Такий підхід містить продуктивний заряд та має велику пояснювальну силу. На наш погляд, при створенні нового образу української історії, слід враховувати не тільки дослідження, які ставлять собі за мету довести «невідворотність» створення незалежної української держави, але й тих, хто не є симпатиком українського національновизвольного руху. Якщо не буде врахована ця обставина, то історія нашої вітчизни замість того, щоб служити справі формування національної самосвідомості та об'єднувати українців, насправді буде лише поглиблювати розкол всередині країни.

Отже, для подолання «маргінальності» вітчизняної філософії історії, слід, на нашу думку, активніше звертатися до здобутків екзистенційно-феноменологічної філософії. Саме вона як така, що фундаментально переглядає уявлення про час та історію, дає можливість представити людину як відповідального суб'єкта історії, дати неесхатологічну відповідь на питання про смисл історії, виявити первинну історичність як основу всесвітньої історії та здійснити її періодизацію на нових засадах. За оцінкою ЖК.-Ф. Ліотара, «багатство цієї філософії, iii „позитивна сторона“ полягає у зусиллі заново осягнути саму людину як суб'єкта історії поза межами об'єктивістських схем, до яких антропологічна наука не може не вдаватися» [5, с. 139]. Історія через її екзистенційне осягнення ніколи не $\boldsymbol{\varepsilon}$ завершеною, тобто людською історією, та не є точно визначеним об'єктом. Але оскільки вона також людська історія, вона не позбавлена смислу. Однак це не означае, що історія має деякий єдиний, необхідний і таким чином фатальний смисл, для якого люди лише іграшки, а також і жертви, як це виявля- 
еться врешті решт у гегелівській філософії історії. Ми переконані, що спираючись на основні методологічні засади феноменології та екзистенціалізму українська філософія історії зможе подолати пережитки натуралізму та фаталістичне тлумачення вітчизняної історії.

\section{1 Бібліографія}

[1] Гайденко П.П. Мартин Хайдеггер: изначальная временность как бытийное основание философии // Вопросы философии. 2006. - o 3. - C. 165-183.

[2] Кимелев Ю.А. «Субъект» и «субъективность» в современной западной социальной философии. - М., 2006.

[3] Козеллек P. Часові пласти. Дослідження з теорії історії. - К.: Дух і Літера, 2006.

[4] Куиерець T.B. Людська присутність як первинний суб'єкт історії у філософії М. Хайдегера // Актуальні проблеми духовності: зб. наукових праць / Відп. ред. Я.В. Шрамко. - Вип. 9. - Кривий Ріг, 2008. - C. 134-143.

[5] Лиотар Ж.-Ф. Феноменология.-СПб.: АЛЕТЕЙЯ, 2001.

[6] Мерло-Понті М. Феноменологія сприйняття.-К.: Український центр духовної культури, 2001.

[7] Мерло-Понти М. Философ и социология // Вопросы социологин.-Том 1.-М.: Адапт, 1992.-С.5-15.

[8] Нові перспективи історіописання. За ред. П. Берка. - К.: НікаЦентр, 2004.

[9] Проценко І.П. Маргінальність як ознака українського історичного дискурсу // Вісник Черкаського університету. Серія Філософія. Випуск 109. - Черкаси, 2007.-С.22-31.

[10] Табачковський В.Г. Людина - Екзистенція - Історія. - К., 1996.

[11] Хайдегеер M. Бытие и время. - M.: Ad Marginem, 1997.

[12] Хайдегеер M. Время и бытие: статьи и выступления.-М.: Республика, 1993. 
[13] Хайдеггер M. Основные проблемы феноменологии.-СПб.: ВРФIII, 2001.

[14] Хайдегеер M. Письмо о гуманизме // Проблема человека в западной философии. - М.: Прогресс, 1988. - С.31-357.

[15] Черняков А.Г. Онтология времени. Бытие и время в философии Аристотеля, Гуссерля, Хайдеггера. - СПб., 2001.

[16] Яковенко Н. Одна Кліо, дві історії // Критика. - 2002. - № 12.C. 13-27.

Надійшла до редакцї 24 січня 2010 р. 